\title{
Pleuropericarditis Associated with Sulphasalazine in a Case of Rheumatoid Arthritis: A Drug-Induced Lupus-Like Syndrome
}

\author{
Romatoid Artritli Bir Olguda Sulfasalazinle İlişkili Plöroperikardit: \\ İlaç Kaynaklı Lupus Benzeri Sendrom \\ Özcan HIZ, ${ }^{1}$ Elif GÜLCÜ, ${ }^{1}$ Yasemin ÖZKAN, ${ }^{1}$ İbrahim TEKEOĞLU, ${ }^{1}$ Nesim ALADAĞ ${ }^{2}$ \\ ${ }^{1}$ Department of Physical Medicine and Rehabilitation, Medical Faculty of Yüzüncü Yıl University, Van, Turkey; \\ ${ }^{2}$ Department of Cardiology, Medical Faculty of Yüzüncü Yıl University, Van, Turkey
}

\begin{abstract}
Pericarditis, a life-threatening condition, can be seen in rheumatic diseases. It may occur secondary to rheumatic diseases or drugs used in the treatment. In this article, we present a case of 47-year-old female, who had joint complaints for 15 years and had treatment of methotrexate and corticosteroid for six years. In the last three months, after the addition of sulphasalazine to her treatment, she developed chest pain, palpitations, rash, fever, and pleuropericarditis and was subsequently diagnosed with systemic lupus erythematosus induced by sulfasalazine. When cardiac disease is seen in a patient with rheumatoid arthritis, medication should be discontinued immediately, and it should be kept in mind that cardiac involvement may be associated with drugs.
\end{abstract}

Key words: Drug-related lupus; rheumatoid arthritis; sulphasalazine.

Cardiovascular involvement in rheumatoid arthritis (RA) is a rare extra-articular finding; however, pericarditis, cardiomyopathy/myocarditis, cardiac amyloidosis, coronary vasculitis, arrhythmia, valvular disorders, congestive heart failure, and ischemic heart disease may be seen in RA.

Pericarditis is the most common heart condition associated with RA and has been reported at a rate of $30-50 \%$ in echocardiographic and post-mortem studies. Despite the high rate of pericarditis, clinical manifestations are found in very few patients, occurring in most patients after the initial diagnosis of arthritis.
Yaşamı tehdit edici nitelikte bir durum olan perikardit romatizmal hastalıklarda görülebilir. Romatizmal hastalıklara ya da tedavide kullanılan ilaçlara sekonder olarak gelişebilir. Bu yazıda, 15 yıldır eklem yakınmaları olan ve altı yıl boyunca metotreksat ve kortikosteroid tedavisi uygulanmış olan 47 yaşında bir kadın olgu sunuldu. Tedavisine sulfasalazin ilave edilmesinden sonraki son üç ayda hastada göğüs ağrısı, döküntü, ateş ve plöroperikardit gelişti ve sonradan hastaya sulfasalazine bağlı sistemik lupus eritematozus tanısı konuldu. Romatoid artritli bir hastada kardiyak hastalık görüldüğünde ilaç tedavisi derhal kesilmelidir ve kardiyak tutulumun ilaçlarla ilişkili olabileceği akılda bulundurulmalıdır.

Anahtar sözcükler: İlaca bağlı lupus; romatoid artrit; sulfasalazin.

However, in some cases, it can be seen before the diagnosis of RA. ${ }^{[1]}$

Therefore, a careful etiologic evaluation should be done in patients with pericardial effusion for the early diagnosis of RA. Pericarditis adversely affects the prognosis of patients, and, especially within the first year of diagnosis, age and cardiac status determine the prognosis. ${ }^{[2]}$

Nonsteroidal anti-inflammatory drugs (NSAIDs), corticosteroids, and/or other immunosuppressive drugs are used in the treatment of pericarditis. A pericardiectomy is required in more serious cases. 
Drug-induced lupus erythematosus (DILE) is defined as an entity characterized by clinical manifestations and immunopathological serum findings similar to those of idiopathic lupus, However, these are temporally related to continuous drug exposure and resolve after the discontinuation of the offending drug.

The typical laboratory profile of DILE consists of positive anti-nuclear antibodies (ANA) and antihistone antibodies, the latter being regarded as the serum marker of this subset.

Demonstration of ANA occurs in approximately two-thirds of the cases. Management is based on the withdrawal of the offending drugs. Topical and/or systemic corticosteroids and other immunosuppressive agents should be reserved for resistant cases. ${ }^{[3]}$

When the symptoms of pericarditis, chest pain, arthritis, arthralgia, rash, and fever are seen, a druginduced, systemic, lupus-like syndrome should be considered. ${ }^{[4-8]}$

In this article, we discuss the reasons for pleuropericarditis in a patient with RA.

\section{CASE REPORT}

A 47-year-old female patient was admitted to the Yüzüncü Yll University Faculty of Medicine cardiology clinic with complaints of shortness of breath and palpitations in August 2009. Medium to severe pericardial effusion was detected in an echocardiography examination. Suspecting cardiac tamponade, fluid was drained immediately and in the screening for pericardial effusion, leukocytosis (7200 leukosytes per mm. cub.) was determined. With the

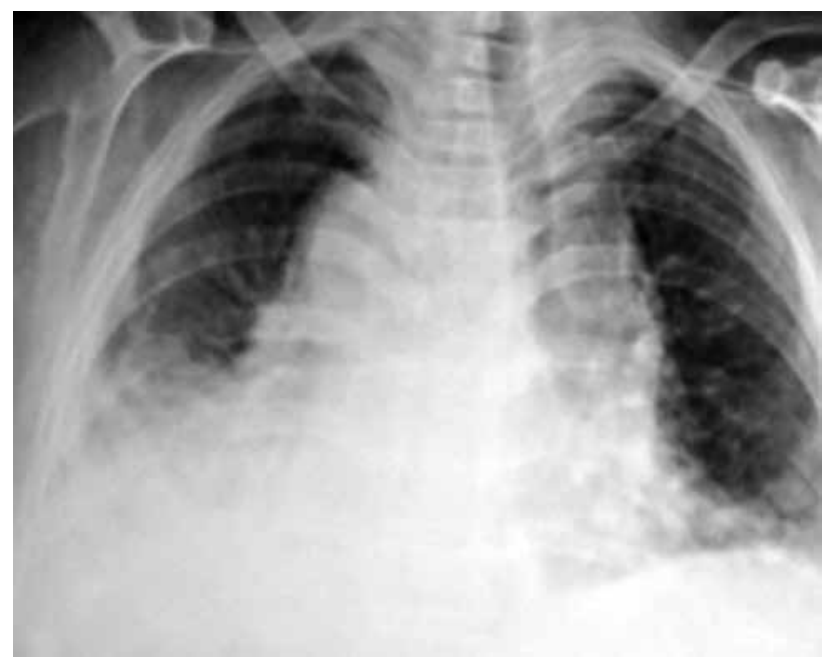

Figure 1. Pulmonary X-rays (pre-treatment). diagnosis of pericarditis, ceftriaxone and ciprofloxacin were started. However, no bacterial reproduction was seen in the patient's pericardial fluid or blood cultures. This appeared to be on account of pericarditis due to rheumatoid arthritis. The patient was conscious and cooperative. She had complaints of widespread joint pain, chest pain, shortness of breath, and palpitations. Three weeks after starting sulphasalazine treatment for fever, the patient developed a swollen nose and cheeks along with erythema on her back. These findings were followed by increased skin complaints when exposed to sunshine. Shortness of breath and palpitations developed afterward. An examination revealed pain, swelling, and increased temperature in the carpometacarpal and metacarpophalangeal joints along with a limitation of motion in the left knee. Ulnar deviation and swan-neck deformity were detected in both hands. Tests revealed a blood pressure of $90 / 60 \mathrm{mmHg}$ and a cardiac pulse rate of $120 / \mathrm{min}$. and a body core fever of 37 centigrate. In a laboratory examination, the following was discovered: leukocyte count 18000, Hgb: $11.5 \mathrm{~g} / \mathrm{dl}$, platelets: 365.000, erythrocyte sedimentation rate (ESR): $34 \mathrm{~mm} /$ hour, CRP: $18.5 \mathrm{mg} / \mathrm{dl}$, GGT: $283 \mathrm{U} / \mathrm{L}$ (5-31), ALT: $40 \mathrm{U} / \mathrm{L}$ (0-31), AST 35 U/L (0-31), LDH: 730 U/L (240-480), RF: $141 \mathrm{IU} / \mathrm{mL}$, and anti-CCP was found to be positive.

A chest radiograph showed an increased cardiothoracic index and medium to severe bilateral pleural effusion which was more pronounced in the posteroanterior right lung (figure 1).

In high resolution computed tomography (HRCT) there was linear atelectasis, and fibrotic changes were found which were more pronounced in the upper lobes of both lungs (figure 2). Mild to severe pericardial effusion

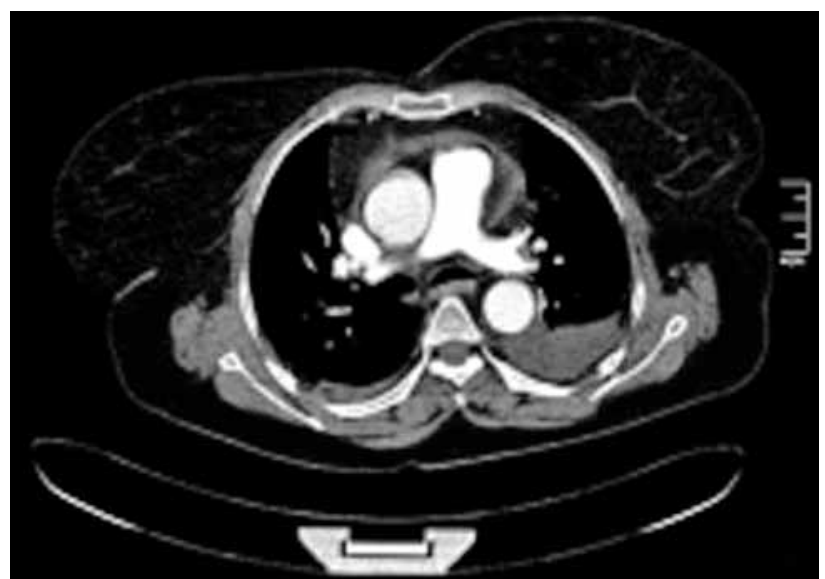

Figure 2. In high resolution computed tomography there, was linear atelectasis and fibrotic changes were found which were more pronounced in the upper lobes of both lungs. 


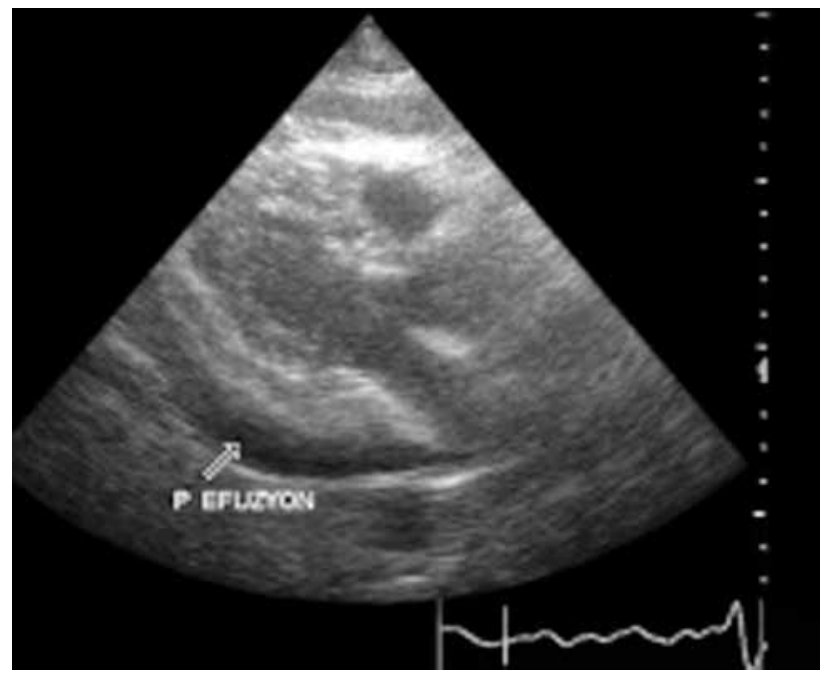

Figure 3. Mild to severe pericardial effusion is seen in echocardiography.

was seen in echocardiography (ECHO; figure 3). Three days after $20 \mathrm{mg}$ intravenous prednisolone therapy, fluid accumulation was considered to be gradually decreasing in ECHO (figure 4).

In the light of present findings, it was thought to be a lupus-like syndrome due to the use of sulphasalazine. Twenty milligram intravenous prednisolone therapy was started, and sulphasalazine was discontinued. Five days later, the ECHO results were considered normal, and the patient was admitted to the rheumatology service to continue a rheumatology examination.

A second control of the laboratory analysis revealed the following: ESR: $34 \mathrm{~mm} /$ hour, CRP: $7.97 \mathrm{mg} / \mathrm{L}$, WBC: 22.7, Hgb: 11.9 g/dl, RF: $37 \mathrm{IU} / \mathrm{mL}$, platelets: 464.000, anti-CCP: positive, ANA: negative, anti-dsDNA: negative, and anti-histone antibodies: positive.

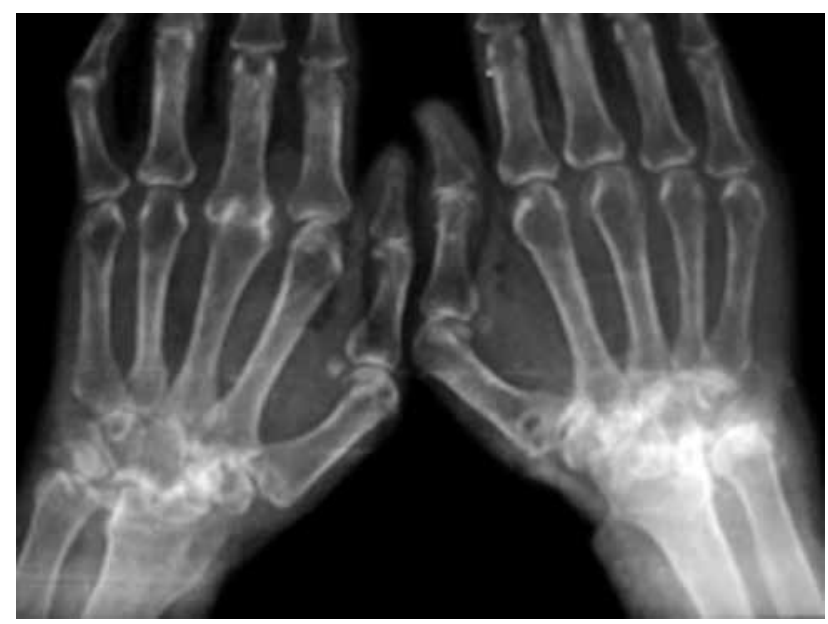

Figure 5. Hand-wrist radiographs.

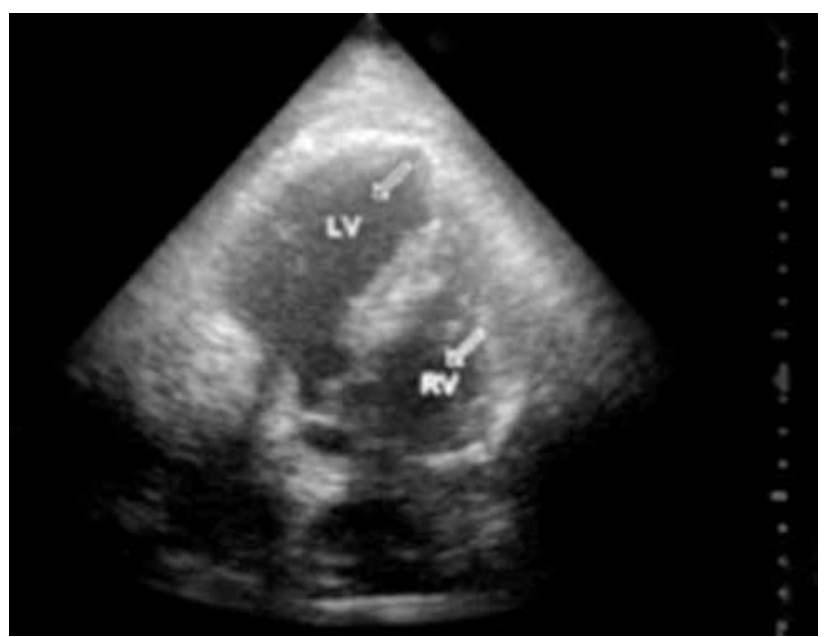

Figure 4. Three days after $20 \mathrm{mg}$ intravenous prednisolone therapy, fluid accumulation was considered to be minimal in echocardiography.

The RA disease activity score (DAS) was calculated as 6.14. Predominant findings in hand X-rays were symmetric joint erosions in carpal bones along with ankylosis leading to contracture, joint space narrowing, cystic changes, and periarticular osteoporosis (figure 5).

In foot-ankle X-rays, periarticular osteoporosis, hallux valgus, and joint space narrowing had progressed to the ankylosis of tarsal bones (figure 6).

Pulmonary X-rays showed moderate and severe bilateral pleural effusion, more pronounced in the right lung, and an increased cardiothoracic index.

The pericardiocentesis fluid and blood cultures were negative, and the control $\mathrm{ECHO}$ was normal in the third and fifth days. The effusion had completely disappeared. Therefore, taking into account all clinical, radiological, and laboratory findings,

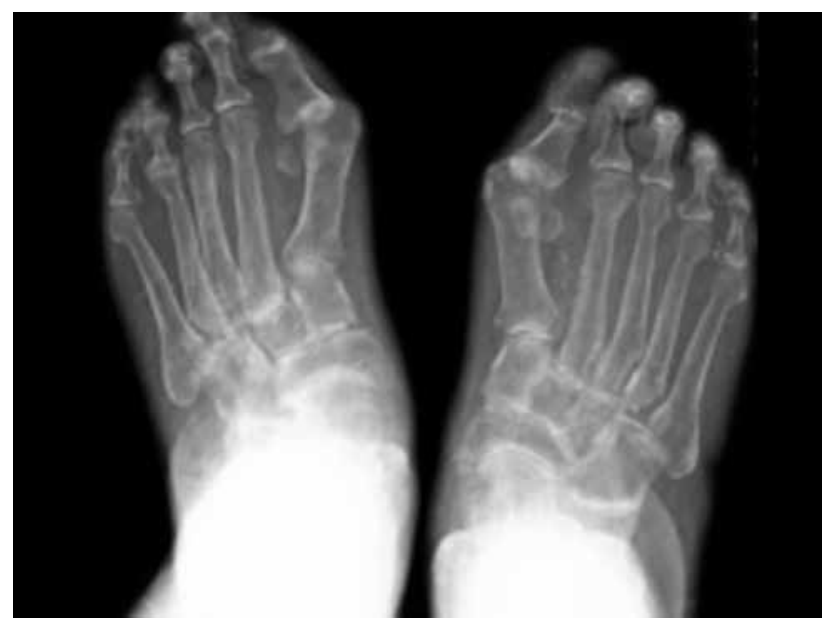

Figure 6. Both foot and ankle radiography. 


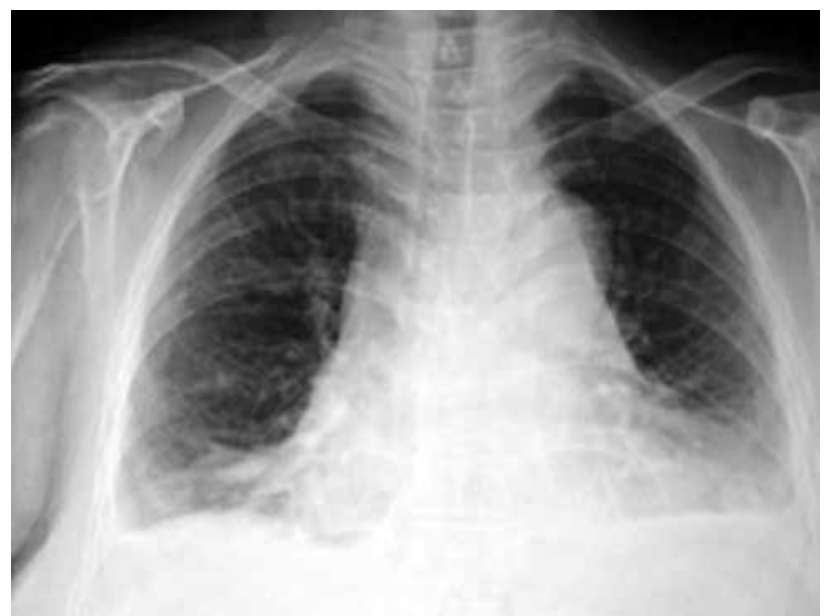

Figure 7. Pulmonary X-rays (Post-treatment).

the patient was diagnosed with DILE due to the use of sulphasalazine. Existing minimal pleural effusion was reported by the pulmonary disease department (figure 7). Liver enzyme and ferritin levels were normal. The other laboratory changes before discharge were as follows: leukocyte count: 18800/mL, Hgb: 12.7 g/dl, CRP: 3.84 mg/L, RF: 37 IU/mL (0-15), ESR: $22 \mathrm{~mm} /$ hour, anti-CCP: positive, ANA: negative, anti-histone antibodies: positive, and anti-dsDNA: negative. Urine analysis findings were within normal limits, and the DAS was calculated as 3.06 .

Prior to discharge, the cardiac examination was normal. After discharge, prednisolone treatment was continued at $16 \mathrm{mg} /$ day (orally), methotrexate at $15 \mathrm{mg} /$ week (subcutaneously) along with folic acid at $5 \mathrm{mg} /$ week.

\section{DISCUSSION}

Approximately 50 drugs that may cause lupus-like syndrome have been reported since 1970. Hydralazine, penicillamine, and procainamide are frequently blamed. Similarly, systemic lupus erythematosus (SLE) patients also have been reported as a result of sulfasalazine use. ${ }^{[9-15]}$

However, diagnosis of DILE in patients with RA is not easy. Because of this, RA and SLE can be found concomitantly.

Sulphasalazine is used quite widely in the treatment of inflammatory bowel disease and rheumatic diseases. It crops components of 5-acetyl salicylic acid and sulfapyridine. Side effects such as reversible sperm abnormalities, pancreatitis, hepatitis, hemolytic anemia (more common in glucose 5-phosphate dehydrogenase deficiency), lung disease, rash, nausea, weakness, and fever can be seen. ${ }^{[16,17]}$

The underlying mechanisms of DILE caused by the use of sulphasalazine could not be fully illuminated in patients with RA.

In the literature, it is said to be a mechanism of pericarditis associated with sulphasalazine hypersensitivity reactions. ${ }^{[7-9,18]}$ However, symptoms typically connected to pericarditis and hypersensitivity start within two weeks after treatment. Habal and Greenberg ${ }^{[19]}$ presented the mechanism of pericarditis in a different way from other authors. They reported findings of pericarditis which occurred after increasing the dosage of sulphasalazine in patients who had been under treatment for 16 years for rheumatoid arthritis A dosage-related mechanism resulting in hypersensitivity reactions related to sulphasalazine is not common. Therefore, the development of hypersensitivity reactions may have resulted from starting sulphasalazine therapy or increasing the current dosage. If such a reaction develops, the drug should be discontinued.

In the present case, although the patient had undergone six years of methotrexate treatment, skin rash, shortness of breath, and palpitations began up to three weeks after starting treatment with sulphasalazine.

High titers of ANA may occur during long-term usage of many drugs. However, in drug-induced lupus, the incidence of asymptomatic serological abnormalities is not known exactly. ${ }^{[20]}$ Anti-dsDNA in DILE is mostly negative. However, these antibodies can develop without symptoms in patients with RA under the treatment of sulphasalazine. ${ }^{[1]}$ In a study, the presence of high titers of anti-dsDNA in most patients with sulfasalazine-induced DILE has been reported. ${ }^{[2,8]}$ In addition, the anti-histone antibody became positive in our case while both the ANA and anti-dsDNA were found to be negative. The presence of ANA or anti-dsDNA need not be a reason to cut off treatment unless clinical findings are overt, but careful monitoring is required. Sulphasalazine is separated into sulfapyridine and 5-acetyl salicylic acid after oral administration, and sulfapyridine acetylation is catalyzed by the $\mathrm{N}$-acetyltransferase- 2 enzyme in the liver. Individuals who have mutations in the gene encoding this enzyme will have slow acetylation. This situation has led to an increase in side effects. However, this slow acetylation effect does not occur in patients with idiopathic SLE. ${ }^{[6,21]}$ 
Gunnarsson et al. ${ }^{[4,6]}$ in their reports discriminated the patients developing SLE and DILE during the sulphasalazine treatment and indicated that the underlying mechanism is the slow acetylation. Therefore, high levels of sulfapyridine were reported to play an important role in the mechanism of DILE.

In our study, no comments could be made regarding this because we did not look for this enzyme in our patient. Cuteneous findings, joint complaints, and serositis are the main clinical features in sulfapyridineinduced DILE.

Arthralgia, fever, and rash have been reported as $33 \%, 25 \%$, and $88 \%$ respectively in drug-induced lupus studies, and severe renal disease has not been reported despite the presence of leukopenia, anemia, vasculitis, and pneumonitis. ${ }^{[22,23]}$

In our case, there were signs of pleural and pericardial effusion along with the chest pain and palpitations associated with arthralgia, fever, and skin rash. The clinical findings improved dramatically within a week after the discontinuation of sulphasalazine and the start of corticosteroid therapy.

In conclusion, the following can be surmised from in this case;

- While receiving methotrexate treatment, the emergence of symptoms of cardiac disease occurred after the addition of sulphasalazine

- Positive cultures were not found in pericardial effusion nor in the blood culture.

- When symptoms of cardiac disease occur in a patient with RA, it should be kept in mind that cardiac involvement is associated with sulphasalazine, and medication should be discontinued immediately.

\section{Declaration of conflicting interests}

The authors declared no conflicts of interest with respect to the authorship and/or publication of this article.

\section{Funding}

The authors received no financial support for the research and/or authorship of this article.

\section{REFERENCES}

1. Voskuyl AE. The heart and cardiovascular manifestations in rheumatoid arthritis. Rheumatology (Oxford) 2006;45 Suppl 4:iv4-7.
2. Mor A, Pillinger MH, Wortmann RL, Mitnick HJ. Druginduced arthritic and connective tissue disorders. Semin Arthritis Rheum 2008;38:249-64.

3. Marzano AV, Vezzoli P, Crosti C. Drug-induced lupus: an update on its dermatologic aspects. Lupus 2009;18:935-40.

4. Gunnarsson I, Nordmark B, Hassan Bakri A, Gröndal G, Larsson P, Forslid J, et al. Development of lupus-related side-effects in patients with early RA during sulphasalazine treatment-the role of IL-10 and HLA. Rheumatology (Oxford) 2000;39:886-93.

5. Gujral N, Friedenberg F, Friedenberg J, Gabriel G, Kotler M, Levine G. Pleuropericarditis related to the use of mesalamine. Dig Dis Sci 1996;41:624-6.

6. Gunnarsson I, Kanerud L, Pettersson E, Lundberg I, Lindblad S, Ringertz B. Predisposing factors in sulphasalazine-induced systemic lupus erythematosus. $\mathrm{Br}$ J Rheumatol 1997;36:1089-94.

7. Demir R, Bodur H, Tokoğlu F, Olcay I, Uçan H, Borman P. High resolution computed tomography of the lungs in patients with rheumatoid arthritis. Rheumatol Int 1999;19:19-22.

8. Matteson EL. Extra-articular features of rheumatoid arthritis and systemic involvement. In: Hochberg MC, Silman AJ, Smolen JS, Weinblatt ME, Weisman MH, editors. Rheumatology. Philadelphia: Mosby; 2003. p. 781-92.

9. Clementz GL, Dolin BJ. Sulfasalazine-induced lupus erythematosus. Am J Med 1988;84:535-8.

10. Laversuch CJ, Collins DA, Charles PJ, Bourke BE. Sulphasalazine-induced autoimmune abnormalities in patients with rheumatic disease. Br J Rheumatol 1995;34:435-9.

11. Caulier M, Dromer C, Andrieu V, Le Guennec P, Fournie B. Sulfasalazine induced lupus in rheumatoid arthritis. J Rheumatol 1994;21:750-1.

12. Carr-Locke DL. Sulfasalazine-induced lupus syndrome in a patient with Crohn's disease. Am J Gastroenterol 1982;77:614-6.

13. Deboever G, Devogelaere R, Holvoet G. Sulphasalazineinduced lupus-like syndrome with cardiac tamponade in a patient with ulcerative colitis. Am J Gastroenterol 1989;84:85-6.

14. Veale DJ, Ho M, Morley KD. Sulphasalazine-induced lupus in psoriatic arthritis. Br J Rheumatol 1995;34:383-4.

15. Hobbs RN, Clayton AL, Bernstein RM. Antibodies to the five histones and poly(adenosine diphosphate-ribose) in drug induced lupus: implications for pathogenesis. Ann Rheum Dis 1987;46:408-16.

16. Kirkpatrick AW, Bookman AA, Habal F. Lupus-like syndrome caused by 5 -aminosalicylic acid in patients with inflammatory bowel disease. Can J Gastroenterol 1999;13:159-62.

17. Capelland H, Madhok R. Disease-modifying antirheumatic drugs 2: sulfasalazine and dapsone. In: Marc C, editor. Rheumatology. 3rd ed.Hochberg: Mosby; 2003. p. $405-16$. 
18. Doganay L, Akinci B, Pekel N, Simsek I, Akpinar H. Mesalazine-induced myopericarditis in a patient with ulcerative colitis. Int J Colorectal Dis 2006;21:199-200.

19. Habal FM, Greenberg GR. Treatment of ulcerative colitis with oral 5-aminosalicylic acid including patients with adverse reactions to sulfasalazine. Am J Gastroenterol 1988;83:15-9.

20. Gordon MM, Porter DR, Capell HA. Does sulphasalazine cause drug induced systemic lupus erythematosus? No effect evident in a prospective randomised trial of 200 rheumatoid patients treated with sulphasalazine or auranofin over five years. Ann Rheum Dis 1999;58:288-90.
21. Alarcón-Segovia D, Kraus A. Drug-related lupus syndromes and their relationship to spontaneously occurring systemic lupus erythematosus. Baillieres Clin Rheumatol 1991;5:1-12.

22. Mongey AB, Hess EV. Sulphasalazine-induced systemic lupus erythematosus. Br J Rheumatol 1994;33:789-90.

23. Reidenberg MM, Drayer DE, Lorenzo B, Strom BL, West SL, Snyder ES, et al. Acetylation phenotypes and environmental chemical exposure of people with idiopathic systemic lupus erythematosus. Arthritis Rheum 1993;36:971-3. 